\title{
Isomorphism, Polymorphism, or Hybridization? South-European Educational Inequalities at Check
}

\author{
¿ेlsomorfismo, polimorfismo o hibridación? \\ Desigualdades educativas en el sur de Europa en revisión
}

Orazio Giancola, Luca Salmieri ${ }^{1}$

\begin{abstract}
While there is a robust consensus on the existence of a South European welfare regime (Ferrera, 1996) and several researches have been consolidating that perspective while underlying national specificities (Rhodes, 1996), researches on cross-country comparisons of educational systems and performances have not been focussed enough to provide a solid framework to identify a common or different educational patterning among countries such as Greece, Italy, Malta, Portugal and Spain (Madeira, 2018; Nóvoa, 2018; Palomba, Cappa, 2018). In this paper, we aim at understanding whether a South-European educational space exist in relation to structural internal features and educational inequalities and whether single national education systems tend toward isomorphism, polymorphism or hybridization.
\end{abstract}

Keywords

South-Europe, educational inequalities, educational policies, ascriptive social factors.

\section{Resumen}

Si bien existe un sólido consenso sobre la existencia de un régimen de bienestar en el sur de Europa (Ferrera, 1996), con varias investigaciones que consolidan esta perspectiva, al tiempo que subyacen las especificidades nacionales (Rhodes, 1996), las investigaciones sobre las comparaciones entre países de los sistemas y los resultados educativos no se han centrado lo suficiente como para proporcionar un marco sólido para identificar un modelo educativo común o diferente entre países como Grecia, Italia, Malta, Portugal y España (Madeira, 2018; Nóvoa, 2018; Palomba, Cappa, 2018). En este trabajo, pretendemos comprender si existe un espacio educativo sur-europeo en relación con las características estructurales internas y las desigualdades educativas y si los sistemas educativos nacionales únicos tienden al isomorfismo, al polimorfismo o a la hibridación.

\section{Palabras clave}

Chronobiology, chronopsychology, attention rhythms, memory rhythms, sleep, right hemisphere, left hemisphere.

\section{Cómo citar/Citation}

Giancola, Orazio y Salmieri, Luca (2022). Isomorphism, Polymorphism, or Hybridization? South-European Educational Inequalities at Check. Revista de Sociología de la Educación-RASE, 15 (1), 8-24. http://dx.doi.org/10.7203/RASE.15.1.22155. 


\section{Introduction}

While there is a robust consensus on the existence of a South European welfare regime (Ferrera, 1996) and several researches have been consolidating that perspective while underlying national specificities (Rhodes, 1996), researches on cross-country comparisons of educational systems and performances have not been focussed enough to provide a solid framework to identify a common or different educational patterning among countries such as Greece, Italy, Malta, Portugal and Spain (Madeira, 2018; Nóvoa, 2018; Palomba, Cappa, 2018). In this brief paper, we aim at understanding whether a South-European educational space exist in relation to structural internal features and educational inequalities and whether single national education systems tend toward isomorphism, polymorphism or hybridization.

\section{Methodology and data}

In order to ascertain whether the geography of South-European educational systems is driven by isomorphism, polymorphism or hybridization, we have analysed different features along a three-steps analyses.

Firstly, we have considered the so-called institutional input factors (Hanushek, Woessmann, 2014) and then we have selected the structure of school-tracking, the age of compulsory schooling, the duration of the general common track for Greece, Italy, Malta, Portugal and Spain.

Secondly, we have observed four main dimensions along a continuum: 1) the levels of centralization/ decentralization in the governance of primary and secondary schools (Jeong, Luschei, 2018). 2) the distribution of student's enrolment among public and private schools (Busemeyer, 2014); 3) Settings, organizations and procedures in schools' accountability (external and internal evaluation activities implemented by official bodies and schools' organisms) (Eurydice, 2019); 4) School's autonomy in decision taking (Christ, Dobbins, 2016; Hanushek et al., 2013).

Thirdly, we have estimated ascriptive social variables affecting educational inequalities among students' performances and school expectations (socio economic and cultural origins, gender inequalities, the immigrant ratio among students and corresponding educational achievements) (Giancola, 2009; Benadusi, Giancola, 2014; Benito et al., 2014). We have relied on secondary data and available empirical literature to compare findings from our first and second steps in analyses. We than have processed OECD-PISA integrated data (both from the student questionnaire and test scores) to compare findings deriving from the third step.

\section{Structural factors of national education systems}

To understand main differences and similarities among national education systems is worthy important to consider how each is structured. As we know, three main organisational models of primary and lower secondary education (ISCED levels 1 and 2) can be identified in Europe (Eurydice, 2020). These education levels are part of compulsory education in all European education systems. The common core curriculum provision is found in all the five southern European country included in this study. In Greece, Italy, Malta, Portugal and Spain together with other continental countries (such as France, Belgium, Romania) after successfully completing primary education (ISCED level 1), all students progress to lower secondary level (ISCED level 2) where they follow the same general common core curriculum. Conversely, single structure education is provided in Scandinavian countries, Poland, and Balkan countries (Czech Republic, Slovenia, Serbia, Croatia, Bulgaria) where all students follow a common curriculum 
providing general education from the beginning to the end of compulsory education and no transition between primary and lower secondary education is provided. Finally, Germany, the Netherlands, Switzerland, Austria offer a differentiated lower secondary education: after successfully completing primary education, students follow distinct educational pathways or specific types of education, which start either at the beginning or in the course of lower secondary education. At the end of their studies, they receive different certificates.

Therefore, except for the ages of passing from primary to secondary education and within secondary education from lower and upper steps, the education system in South European countries can be considered as uniform. Relevant differences among the selected countries emerges regarding the axes of centralisation/ decentralisation, school's autonomy, school's accountability and public vs private education. We present and discuss data and information about those axes by coupling first schools' decentralisation with the distribution of student between public and private schools and then autonomy and accountability.

\section{Decentralization, privatisation, autonomy, and accountability}

Viewing educational systems as complex sets of institutions in which different actors operate with different but interdependent roles and contributions, we believe that the decentralization or centralization along dynamics in decision taking influences performance profile and educational practices (da Cruz Martins et al., 2019; Wermke, Salokangas, 2015). Decentralization in the decision-making process means the increased capacity and opportunity to make decisions by delegation of the central authorities as well as with reference to the specific territorial contexts of schools. This dimension of school governance is closely linked to the general structure of a national education system, its administrative structure and the general design in the management of choices regarding school policies.

In turn, in the various European education systems, school governance is the result of a long and often contradictory historical construction not only for the education sector, but for State organizations and public policies at large. In recent decades, the belief that decentralization and increased school autonomy make an unequivocal contribution to increased educational quality has been very persistently stated (Maslowski et al., 2007). As in other cases, this assertion has not been without controversy (Altrichter $e t$ al., 2014; da Cruz Martins et al., 2019).

Relying on a calculation done by da Cruz Martins and colleagues (2019), we can assess how much responsibility is averagely distributed among local schools and other bodies of governance according to country. The estimation is based on the distribution of the various countries according to the percentage of decisions taken at different levels of educational governance, from the most centralized (State and Regions) to the most decentralized (local authorities and schools). Data are from 2015 OECD PISA international survey. Countries in Europe where central education bodies have more responsibility for decision-making than schools are a minority (Graphic 1). This group consists mainly of Central European countries and three among the five Southern European countries we are considering in our analysis: Greece, Portugal and Spain. Since its small territory, Malta is not considered in the analyses, while Italian schools show higher degrees of regional responsibility, even if they nevertheless have a low level of autonomy in decision taking when compared to schools in the Scandinavian and Baltic area. In those latter countries, high levels of participation of local and/or regional authorities in educational decisions are paired with high levels of school autonomy. 
On the other hand, national contexts where the central state is next in line to schools in terms of decisions taken include a set of Eastern European countries (Poland, Slovenia and Slovakia) and Central Europe (Belgium and the Netherlands). It is thus noteworthy that, depending on the context, school autonomy may be an expression of a broader process of territorial decentralization (Christ, Dobbins, 2016).

\section{Graphic 1. Percentage of decisions taken at each level of government in public lower secondary education (2017)}

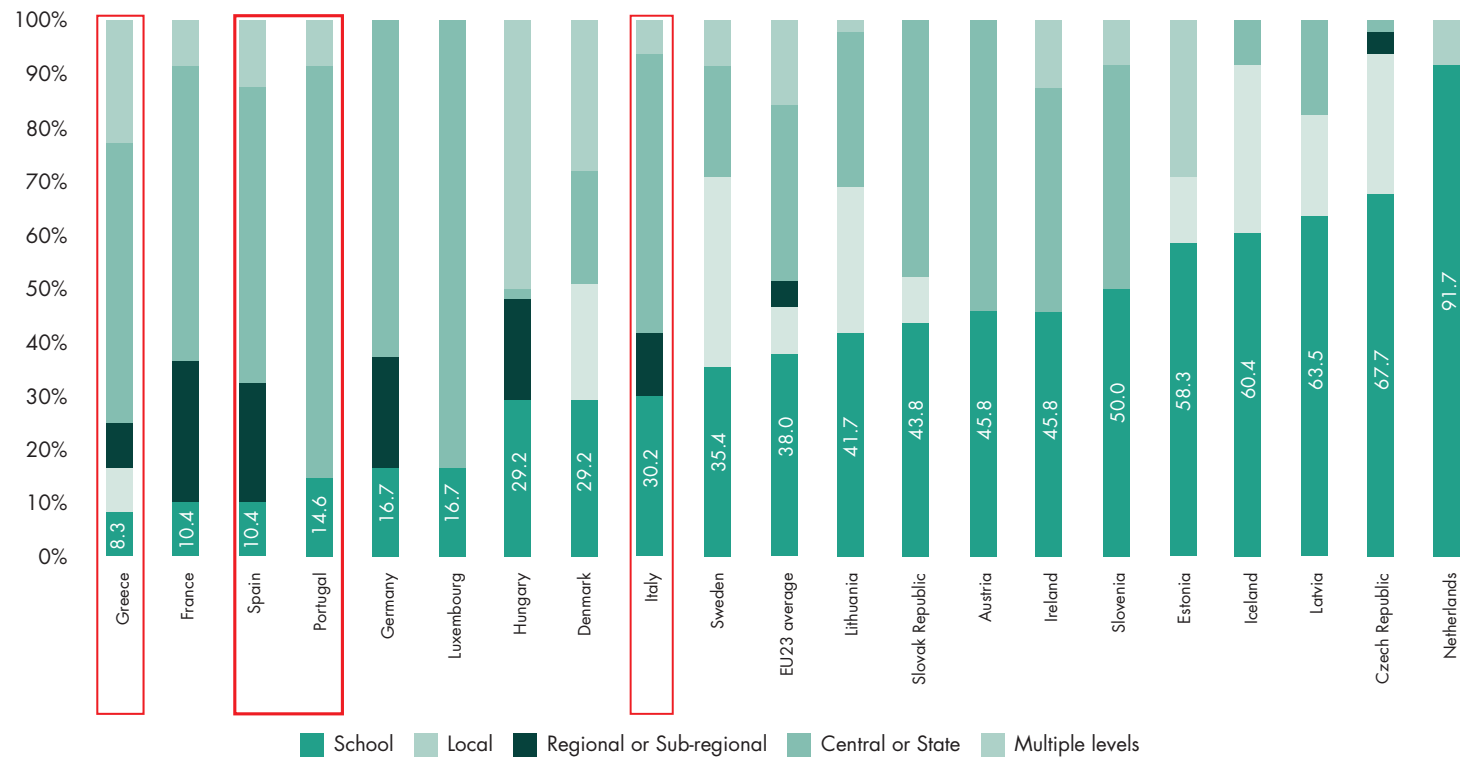

Source: OECD (2018), Table D6.1.

As it is commonly known, over the past two decades, education policies involving private schools, school competition and school choice have been the focus of sometimes heated debate in a growing number of countries (Forsey et al., 2008; Adamson et al., 2016). According to advocates of school choice, expanding the availability of schools can improve student outcomes because doing so provides incentives for schools, both public and private, to improve their instructional quality. But the evidence on this is not conclusive (Urquiola, 2016), Rather, the main worry that the increasing involvement of private institutions in the education system may be correlated with a further imbalance in student performance and education equity according to social origins and economic inequalities finds evidence from empirical observations. Data and analyses considering this issue reveals that the rate of private school enrolment both across the whole set of European countries and specifically across South-European countries have been growing over time and the relationship between school type and student performance have been exacerbating social inequalities measured via the socio-economic profile of public and private schools (Ball, Youdell, 2008). Moreover, some research warns that school choice can unintentionally widen already existing inequities in education because socio-economically disadvantaged families are more constrained in their choice of school than advantaged families (Rowe, Lubienski, 2017).

We here define public schools as those managed by a public education authority, government agency, or governing board appointed by government or elected by public franchise. Private schools refer to schools managed directly or indirectly by a non-government organisation (such as a church, trade union, 
business or other private institution). Among private schools there are those funded mainly through student fees or other private contributions such as benefactors and donations (government-independent private schools) and those privately managed and receiving substantial (more than half) funding from government sources. As we can gauge from Graphic 2, Italy, Greece and Portugal display a high share of enrolments in public primary and secondary schools ranging from $86,6 \%$ in Portugal to $96,4 \%$ in Italy. In opposition, one Spanish students in three (32,3\%) enrol in private schools (above all government-dependent private schools). Malta stands apart from the group, since a slight majority of Maltese students are in public schools $(55 \%)$, but a very significant share of students opts for private schools.

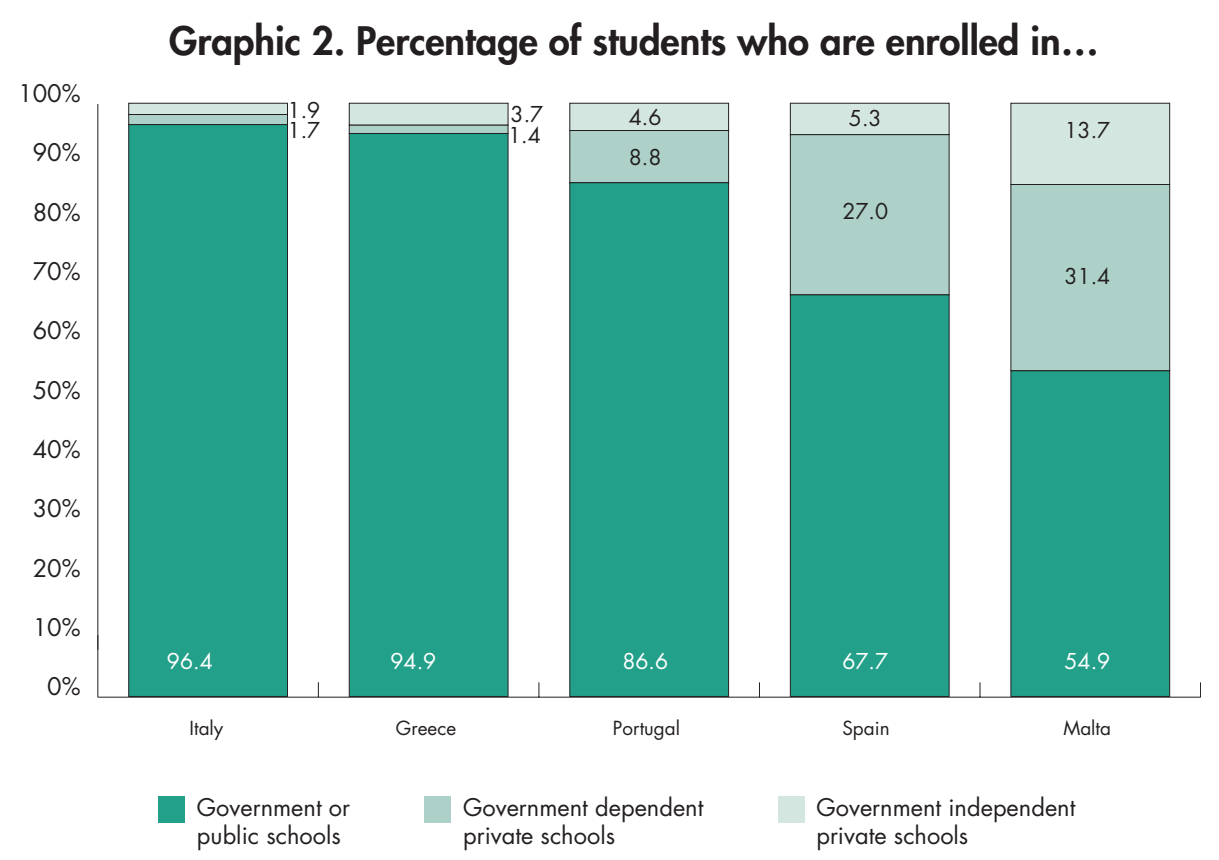

Source: OECD, PISA 2018 Database, Table V.B1.7.1.

Education systems where significative shares of students attend private schools are typically those in which the government provides substantial funding for private schools to operate, as it is the case in Spain and Malta. But while in Spain four on five students in private school attend a government-dependent private school, in Malta the proportion is three on five, meaning that two on five students attend a government-independent private school.

On average across European countries, students in private schools scored higher in Reading than students in public schools (before accounting for socio-economic profile). However, after accounting for students' and schools' socio-economic profile, Reading scores are higher in public schools than in private ones. That fully applies for the South-European cluster we selected, except for Malta that is a case apart. Since 1988, Malta educational establishments in the non-state as well as the state sector are legally bound to provide the same National Minimum Curriculum, so that in theory at least, the difference in what is formally taught and tested in all primary, secondary and post-secondary educational establishments is slight, with practically all students sitting the same Secondary Education Certificate (SEC) and Matriculation examinations. 


\section{Graphic 3. Change between 2000 and 2018 in enrolment in public and private schools}

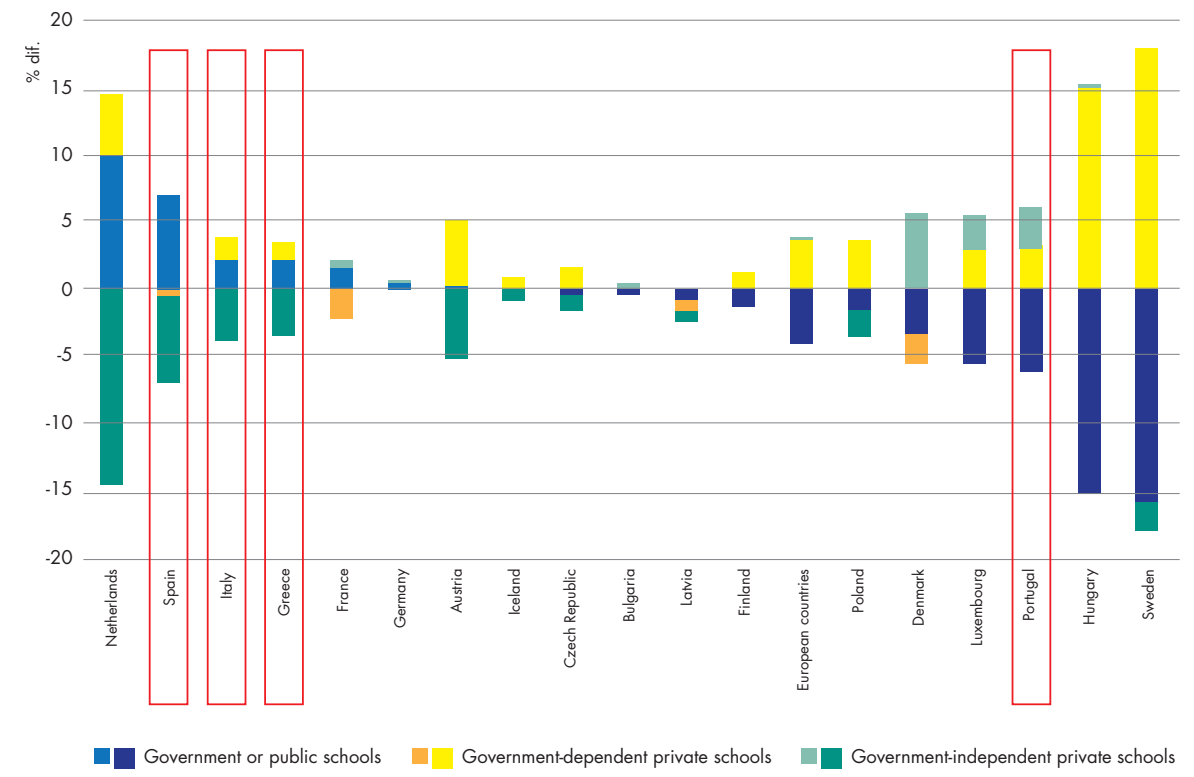

Source: OECD, PISA 2018 Database, Table V.B1.7.1.

Notes: Countries and economies with a statistically significant change between PISA 2000 and PISA 2018 in the percentage of students enrolled in public, private-dependent or private-independent schools are shown in a darker tone when values are negative.

\section{Table I. Country positioning along the axes of governance decentralization and school privatization}

\begin{tabular}{|c|c|c|c|c|}
\hline \multirow{5}{*}{ 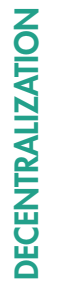 } & \multicolumn{4}{|c|}{ PRIVATIZATION } \\
\hline & & - & 0 & + \\
\hline & - & $\begin{array}{l}\text { Greece } \\
\text { Portugal }\end{array}$ & Spain & Malta \\
\hline & 0 & Italy & & \\
\hline & + & & & \\
\hline
\end{tabular}

Source: Authors' estimation.

In general, across all democratic countries and advanced economies, school systems with larger shares of students in private-independent schools tended to show lower mean performance in Reading. At the same time social inequalities reproduced via educational performances and achievements tend to be wider when a significant private educational sector is an upper-class destination being secluded to lower classes (OECD, 2012). As we report in Table I, there seems to be a slight isomorphy among South-European countries concerning decentralization and privatization of school governance and enrolments. Greek and Portuguese education systems look similar when data from lower secondary schools are taken in account, with Spain and especially Malta differing based their share of private schools and with Italy standing just slightly apart based on its higher rate of decentralization (Pensiero et al., 2019).

Let us now turn to schools' autonomy. We think that school autonomy does not totally correspond to decentralized governance. While this latter define a process through which regional, local and community bodies exert a stronger influences on educational policies, autonomy for local schools can be interpreted as the capability to take decision concerning: i) the organization of teaching such as educational paths, lesson times, choice of textbooks; constitution of classes; teaching methods; ii) the personnel manage- 
ment i.e., hiring and firing of teaching and non-teaching staff; conditions of service; influence on careers; iii) the planning and structures that is design of study programmes, definition of course content, and iv) the resources for teaching staff, non-teaching staff, capital and operating expenses (da Cruz, 2019). These dimensions have been aggregated by OECD-PISA experts in a general index of school autonomy on a scale ranging from 0 to 100 . However, despite this classification, the OECD itself has used others in various assessments over time editions. Therefore, being extremely cautious about the complexity regarding the meanings of school autonomy, we can observe that among the European countries which have the lowest rates of school autonomy are those in Southern Europe (Greece, Malta, Italy, Spain and Portugal) and it is noteworthy that Greece has very limited school autonomy even compared with the cluster (Graphic 3).

\section{Graphic 3. Index of school autonomy, European Union countries}

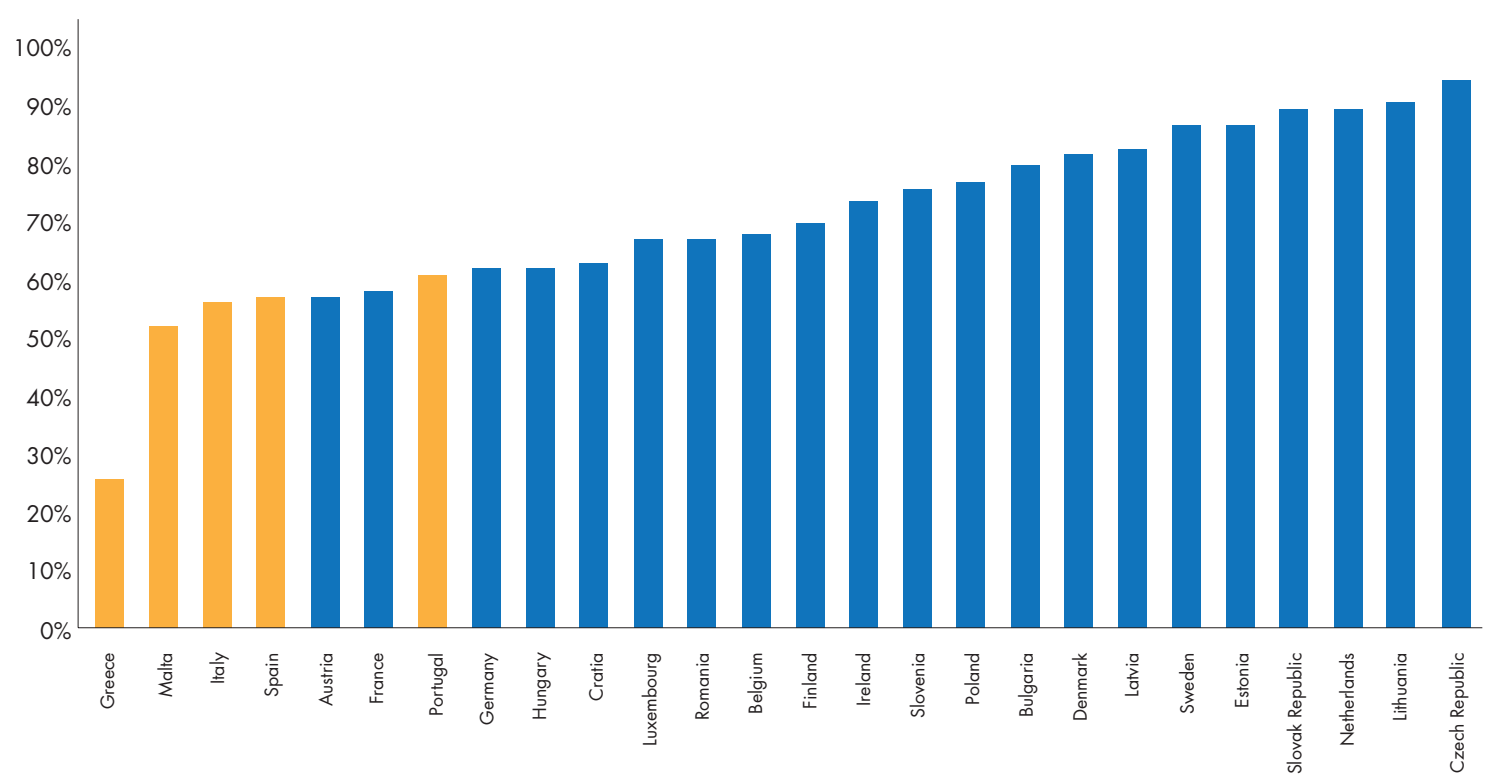

Source: OECD (2015), PISA (Data).

It remains to be seen what the substance of this autonomy has been in the various areas of schools' responsibilities in decision taking. Considering whether decisions on different domains are taken by school bodies, local authorities, local regional or sub-regional institutions or by multiple levels, we have a snapshot on South-European cluster, except for Malta (see next Table II). 


\section{Table II. Percentage of decisions taken at school and multiple levels government in public lower secondary education, by domain (2017)}

\begin{tabular}{|c|c|c|c|c|c|c|}
\hline DOMAINS & & GREECE & ITALY & PORTUGAL & SPAIN & EU AVERAGE \\
\hline \multirow[t]{2}{*}{ Organisation of instruction } & School & 33 & 67 & 33 & 33 & 53 \\
\hline & Multiple levels & & & 33 & & 14 \\
\hline \multirow[t]{2}{*}{ Personnel management } & School & 0 & 8 & 25 & 8 & 29 \\
\hline & Multiple levels & 25 & & & 33 & 19 \\
\hline \multirow[t]{2}{*}{ Planning and structures } & School & 0 & 33 & & & 36 \\
\hline & Multiple levels & 17 & & & 17 & 19 \\
\hline \multirow[t]{3}{*}{ Resource management } & School & & 13 & & & 33 \\
\hline & Multiple levels & 50 & 25 & & & 13 \\
\hline & Total & 125 & 146 & 91 & 91 & 216 \\
\hline
\end{tabular}

Source: OECD (2018), Education at glance. Authors' calculation.

Concerning the domain of organisation of instruction, Greece and Spain share a similarly low level of school autonomy; Portugal has a low level of school autonomy accompanied by decision taken also on multiple levels, and Italy a medium level of school autonomy and no decision taken at multiple level (Giancola, Salmieri, 2022). Decisions on personnel management relies partially on schools in Portugal, while Greek, Italian and Spanish schools are cut off. Decisions in this domain are taken at multiples levels in Spain and Greece, even if with rare occurrences. Planning and structures are included in schools' decisions only in Italy and in multiple levels processes in Greece and Spain. Finally, resource management issues are included in Italian school autonomy at low rate, while being excluded by school autonomy in Greece, Portugal and Spain. Greek schools conversely take part in multiple levels decisions concerning resource management. We can conclude that when compared to the others European countries, even if according to the index of school autonomy South-European education systems display school low autonomy, the ability to take decisions at school and multiple level varies in each country according to the specific domain we account for.

The fourth and last dimensions of our analyses regards accountability. In this case we do not have data and indexes which allow to produce ordered estimation. We have to rely on a qualitative interpretation of structure and processes of evaluation, distinguishing external from internal evaluation. The former is normally conducted by evaluators who are not staff members of the school concerned, and reporting to authorities responsible for education, while the latter is performed primarily by members of school staff.

Relying on Eurydice (2015) report on policies and approaches to school evaluation in Europe, we have identified main features of each South-European country system for schools' accountability (Table III). In this area of structured organization, variation is the common dimension across Europe. Therefore, is not a surprise that among Greece, Italy, Malta, Portugal and Spain the system of school evaluation varies according to the type of body and institution which perform evaluation, the historical endurance of each national and local set of procedure, the type of combination between external and internal evaluation, specific goal, remedies and effects of evaluation.

In Greece external evaluation by the inspectorate is concerned mainly with teachers, while no other type of evaluation is provided. Although some external evaluation of schools exists in this country, it is fairly limited in scope as it is related to specific items, such as financial accounts, health, safety, archives, 
and other matters. Italy is one of latest countries in Europe to have introduced and implemented a stable and structured external evaluation system. Among the South European evaluation system is the only providing eventual disciplinary actions for schools. Greek, Italian, Maltese and Spanish education systems rely on the principle that evaluation reports cannot be used by parents and pupils to choose the schooling establishment, while that is the case for the Portuguese even if margins for choice are limited.

Table III. Main features of the external evaluation on schools, by country. 2017

\begin{tabular}{|c|c|c|c|c|c|}
\hline & EXTERNAL BODY & STARTING YEAR & OCCURRENCE & $\begin{array}{c}\text { RELATION WITH } \\
\text { INTERNAL EVALUATION }\end{array}$ & $\begin{array}{c}\text { EFFECTS OF EXTERNAL } \\
\text { EVALUATION }\end{array}$ \\
\hline GREECE & & No external evaluation & & Framework and indicators & $\begin{array}{l}\text { Results from the auto evaluation } \\
\text { must be published on schools' } \\
\text { websites }\end{array}$ \\
\hline ITALY & $\begin{array}{l}\text { INVALSI } \\
\text { Specific framework with parame- } \\
\text { ters and standards }\end{array}$ & 2016 & $\begin{array}{l}\text { Every year on randomly selected } \\
\text { schools }\end{array}$ & $\begin{array}{l}\text { Based both on indicators, } \\
\text { assessments and on school auto } \\
\text { evaluation }\end{array}$ & $\begin{array}{l}\text { Eventual remedial actions. } \\
\text { № publicity of evaluation results }\end{array}$ \\
\hline MALTA & $\begin{array}{l}\text { QAD + DQS. } \\
\text { Ministry for Education and } \\
\text { Employment Specific framework } \\
\text { with parameters and standards }\end{array}$ & 2014 & $\begin{array}{l}\text { All schools. } \\
\text { No specific frequency }\end{array}$ & $\begin{array}{l}\text { Schools' action plans based on the } \\
\text { internal evaluation. }\end{array}$ & $\begin{array}{l}\text { Eventual remedial actions. } \\
\text { All schools receive an unannounced } \\
\text { one-day follow-up visit within one } \\
\text { calendar year from publication of } \\
\text { the evaluation report. } \\
\text { Disciplinary actions }\end{array}$ \\
\hline PORTUGAL & $\begin{array}{l}\text { IGEC } \\
\text { Specific framework with parame- } \\
\text { ters and standards }\end{array}$ & 2002 & $\begin{array}{c}\text { At least every } 5 \text { years. } \\
\text { For schools given a low grade, } \\
\text { every } 1 \text { year }\end{array}$ & $\begin{array}{l}\text { The reference framework used by } \\
\text { external evaluators includes the } \\
\text { impact of self-evaluation on plan- } \\
\text { ning, organisation and professional } \\
\text { practices. } \\
\text { External evaluators assess how } \\
\text { internal evaluation is conducted }\end{array}$ & $\begin{array}{l}\text { Eventual remedial actions. } \\
\text { Discussion with the school leader } \\
\text { and teachers. } \\
\text { Obligation for schools to deliver } \\
\text { an action plan that addresses the } \\
\text { weaknesses identified. } \\
\text { Reports are public }\end{array}$ \\
\hline SPAIN & $\begin{array}{l}\text { Autonomous communities. } \\
\text { List of topics to cover/indicators } \\
\text { to consider. National Education } \\
\text { System Indicators }\end{array}$ & 2006 & $\begin{array}{c}\text { Annual determination of the criteria } \\
\text { against which schools are selected } \\
\text { to be visited }\end{array}$ & $\begin{array}{l}\text { Plan for School Improvement } \\
\text { that schools must draft taking } \\
\text { into account the results of the } \\
\text { Diagnostic Evaluation of students' } \\
\text { performances. }\end{array}$ & $\begin{array}{l}\text { Eventual remedial actions. } \\
\text { Obligation for schools to deliver } \\
\text { an action plan that addresses the } \\
\text { weaknesses identified. No publicity } \\
\text { of evaluation results. } \\
\text { Financial support }\end{array}$ \\
\hline
\end{tabular}

Source: Authors' elaboration from Eurydice (2015).

\section{Table IV. Intersection between autonomy and accountability in primary and secondary schools in South-European countries}

\begin{tabular}{|c|c|c|c|c|}
\hline \multirow{5}{*}{ 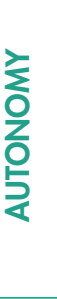 } & & \multicolumn{2}{|c|}{ ACCOUNTABILITY } & \multirow[b]{2}{*}{+} \\
\hline & & - & 0 & \\
\hline & - & Greece & Portugal & $\begin{array}{l}\text { Spain } \\
\text { Malta }\end{array}$ \\
\hline & 0 & & Italy & \\
\hline & + & & & \\
\hline
\end{tabular}

Source: Authors' estimation.

We can conclude that regarding school accountability we have at least three different configurations among the five South-European countries. A very soft type of accountability that concerns the Greek system; a mixed structured system of accountability based both on State external evaluations carried on selected schools and universal school auto-evaluation which is found in the Italian and Portuguese cases 
and, finally, a more intruding and disciplinary based evaluation system which is more typical of the Maltese and Spanish contexts.

Now, combining data and interpretation on school autonomy and the structure and processes of external and internal evaluation, we can conclude that countries from the South-European area seem to differ al lot one to each other (Table IV). Furthermore, we can also draft a final analytical space of multidimensional relations among the South-European countries based on the components we have analysed: decentralization, privatisation, accountability and autonomy plus the three dimensions which substantiate the education system in each country, that are the duration of the common track, the age of compulsory schooling and the type of tracks.

Outputs can be found in Graphic 4, that is the analytical set of relations positing Greece, Italy, Malta, Portugal and Spain educations systems in a two-dimensional space is characterised by polymorphism: Portugal, Spain and Malta show a certain degree of similarity, but in one-to-one relation and not as a homogeneous cluster: as a matter of fact, Malta educations system resembles the Spanish one for a certain dose of privatisation and a strict pursuit of schools' accountability and the Portuguese education system resemble the Maltese, but not the Spanish one. Italian and Greek system, on the contrary are far different one from each other and both differs «differently» from the group of Portugal, Malta and Spain taken together.

\section{Graphic 4. Principal components analysis. Components plot in a rotated component space}

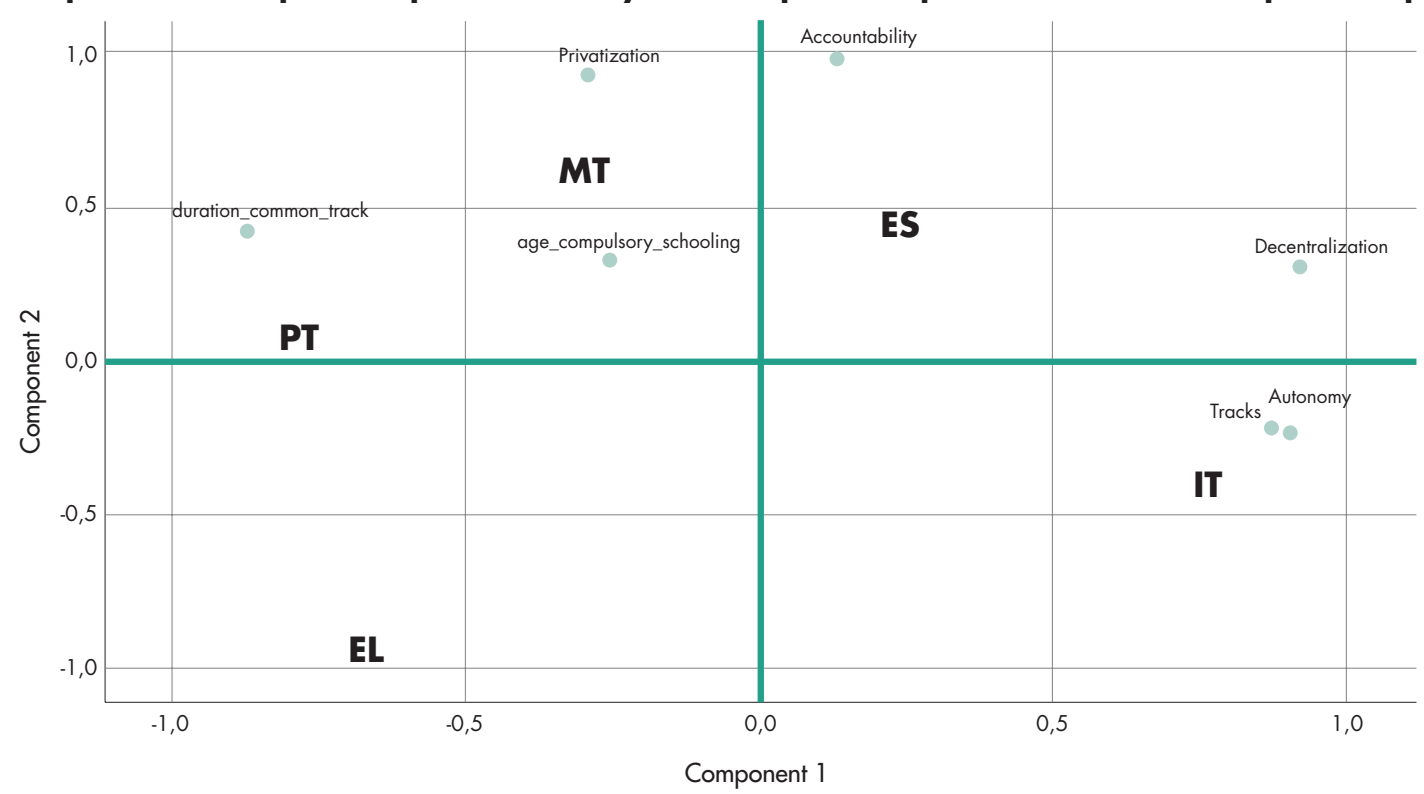

Source: Authors' elaboration.

\section{Inequalities at check}

Test-based assessments conducted on the 15 years old student's population as part of the OECD-PISA survey attests that in the five South-European countries performances scores are below the OECD average both in Mathematics and Sciences. Considering Mathematics, Portugal's and Italy's average score are higher than Spain's one and much higher than in Malta and Greece. We do not consider these scores as indicators that reveal per se the actual and effective learning reality of students. Rather, we rely on these scores to observe if and how inequalities of origin impact differently or similarly in the five countries. 
Looking at «inter-individual inequality» (GERESE, 2005), measured by the standard deviation of the national average score, there is no marked inhomogeneity, except for Malta where low performance and marked difference between individual students are combined. Is this feature explicable by privatisation?

On the average, Portuguese and Spanish students perform higher than Italian students and much higher than Greek and Maltese students. Again, the level of homogeneity is constant among the group of countries, except for Malta.

Table V. Mean scores in Maths and Sciences and standard deviations by country. 2018

\begin{tabular}{lcccc}
\hline & MEAN MATHS & STAND. DEVIATION MATHS & MEAN SCIENCES & STAND. DEVIATION SCIENCES \\
\hline GREECE & 451 & 81,3 & 452 & 80,1 \\
\hline ITALY & 487 & 88,5 & 468 & 85,6 \\
\hline MALTA & 472 & 95,8 & 457 & 101,8 \\
\hline PORTUGAL & 492 & 90,7 & 492 & 87,5 \\
\hline SPAIN & 481 & 80,0 & 483 & 82,4 \\
\hline
\end{tabular}

Source: OECD PISA 2018 database.

Let us now follow the approach of GERESE (2005), according to which those educational systems in which ascribed inequalities tend to impact more than learning outcomes are internally unequal. We therefore look at inter-categorical differences: for each country we have developed two sets of multiple regression models based on students' scores in Mathematics and Science in OECD-PISA tests. Findings show that Portugal, despite being the country with the best relative performances in Mathematics and Sciences, is also the most unequal country among the five considered.

However, to better understand the reproduction of inequalities, it is crucial to assess at what extent student's socio-cultural and economic background affects educational achievements. Our analysis confirms the polarization processes taking place in Portugal, where social origin exerts a major influence on the results in Mathematics and Sciences. At the opposite, we find Italy, where family backgrounds exercise a relatively weaker influence. Spain, Greek and Malta stem out in an intermediate position (for Spain, see also: Salmieri, Giancola, 2021).

Table VI. Inequalities in performances. Multiple regression models: Maths. 2018

\begin{tabular}{lcccc}
\hline & R2 (MATHS) & $\begin{array}{c}\text { INDEX OF ECONOMIC, } \\
\text { SOCIAL AND CULTURAL STATUS }\end{array}$ & NATIVE VS NON-NATIVE & \multicolumn{1}{c}{ FEMALE VS MALE } \\
\hline GREECE & 0,154 & 0,356 & 0,095 & $-0,017$ \\
\hline ITALY & 0,131 & 0,335 & 0,056 & $-0,084$ \\
\hline MALTA & 0,135 & 0,365 & 0,011 & $-0,061$ \\
\hline PORTUGAL & 0,2 & 0,426 & 0,107 & $-0,056$ \\
\hline SPAIN & 0,16 & 0,37 & 0,089 & $-0,054$ \\
\hline
\end{tabular}

Source: OECD PISA 2018 database.

We have also observed that in all countries being native has a relative positive effect on the likelihood to perform better in Mathematics and Sciences. There is a relatively uniform effect across country, even if once again the effect has a peak in Portugal. Within a lower explanatory dimension, being female has a 
negative effect on scores in Mathematics in each country, while the effect on scores in Sciences is slightly different according to country.

Table VII. Inequalities in performances. Multiple regression models: Sciences. 2018

\begin{tabular}{|c|c|c|c|c|}
\hline & R2 (SCIENCES) & $\begin{array}{l}\text { INDEX OF ECONOMIC, } \\
\text { SOCIAL AND CULTURAL STATUS }\end{array}$ & NATIVE VS NON-NATIVE & FEMALE VS MALE \\
\hline GREECE & 0,14 & 0,328 & 0,104 & 0,056 \\
\hline ITALY & 0,103 & 0,288 & 0,095 & $-0,013$ \\
\hline MALTA & 0,124 & 0,339 & $-0,016^{*}$ & 0,1 \\
\hline PORTUGAL & 0,181 & 0,415 & 0,074 & $-0,034$ \\
\hline SPAIN & 0,121 & 0,326 & 0,069 & $-0,026$ \\
\hline
\end{tabular}

Source: : OECD PISA 2018 database.

*Coefficient not significant.

To have a snapshot including the entire set of input factors - decentralization, privatisation, accountability, autonomy, duration of the common track, age of compulsory schooling and type of tracking and output factors — inequalities and students' performances — we have performed a PCA (Principal Component Analysis) (Graphic 5). The analysis has generated two main components: social inequalities with respect to performances and a component encapsulating average performances. Therefore, each country has a relational position in a double dimensional space where distances among them «assess» the extent of similarity and difference. The centre in the scatter plot is a hypothetical country with an education system where social inequalities count zero, differences among students' performances are nil and decentralization, privatisation, accountability, autonomy, duration of the common track, age of compulsory schooling and type of tracking are in a perfect intermediate extension.

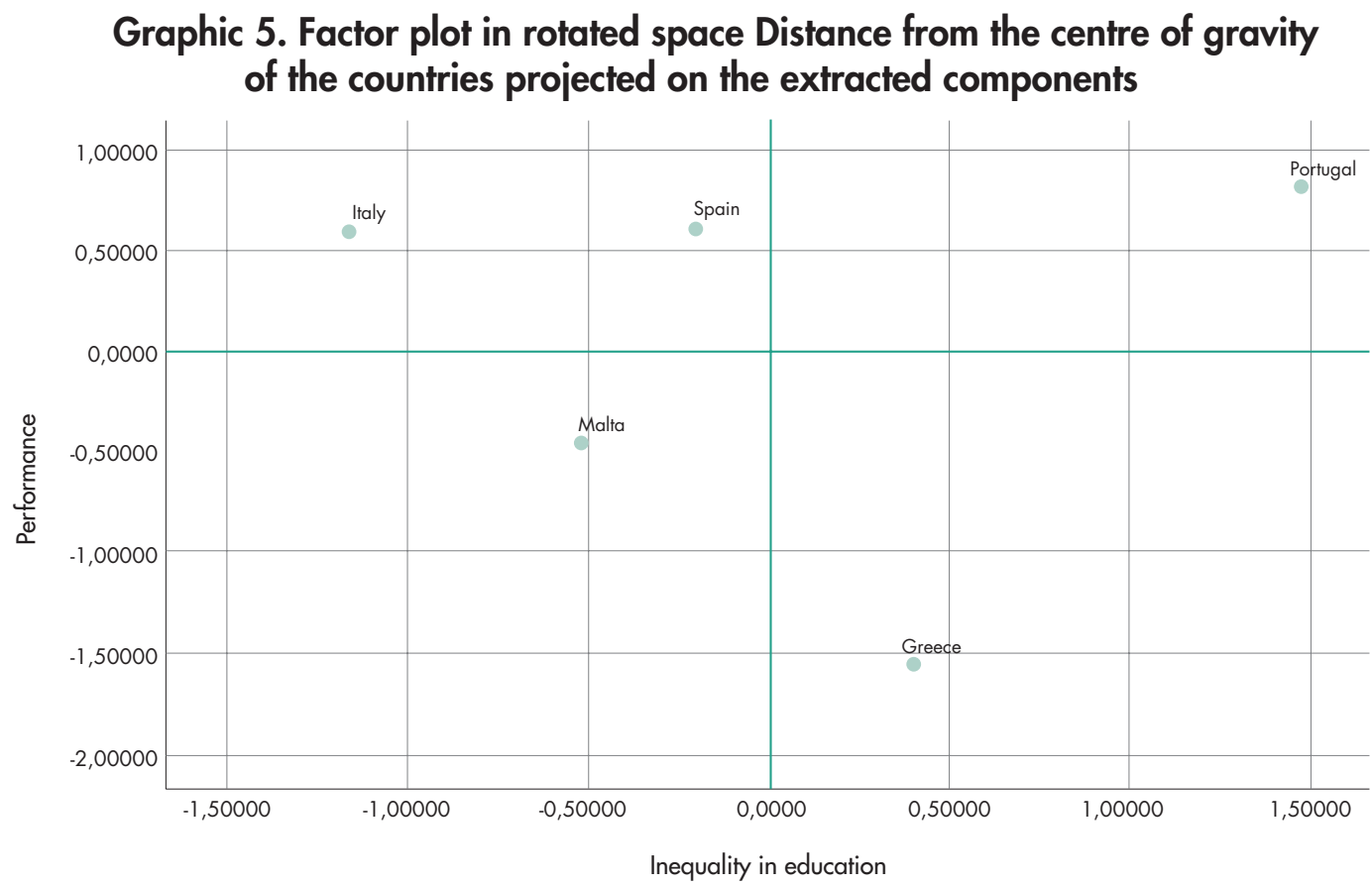

Source: Authors' elaboration. 
South-European countries result to be settled in different positions, each occupying a different quadrant, except for Italy and Spain which share the same quadrant. Italian, Spanish, and Portuguese education systems are similar for the average students' performances, but sharply differs for inequalities among students. Spanish, Greek and Maltese education systems are quite convergent for the extent of inequalities among students, but are quite different in terms of students' performances. Italy and Spain show a consonance in terms of medium-low inequalities and relatively medium performances, even if in Italy social inequalities correspond to marked inequalities in performances based on upper secondary school-tracks (Giancola, Salmieri, 2020); Malta and Greece are characterized by low performances and by medium intense inequalities. Therefore, we overall observe polymorphism as the main feature of South-European education systems.

\section{Conclusions}

The aim of the paper was discussing the ratio of the 'south' with the intertwining of similar traits and country-specific aspects among the countries education systems we considered. The area loosely indicated as 'South-Europe', including Italy, Spain, Portugal, Greece and Malta, has no doubt some cultural affinities and long-lasting historical and cultural interactions. Nonetheless, it has very different positions in 'education dynamics', which have an obvious influence on comparative education and other fields of study and on the dialectics that single country traditions have maintained with the prevailing international discourse. This important facet leads us to support the idea that there are certainly forms of cultural hybridization, but it is immediately manifest that whatever criterion one may choose, there never is a perfect overlapping: Italy, Spain and Portugal are Latin, but Greece is not; Greece is Mediterranean, but not Latin; and of course, Portugal is not Mediterranean. But, further, in terms of sociology of education what matters most is that cultural hybridizations have a less marked power to affects educational systems. Of course, the convergence towards a European centre of gravity is undeniable as the Bologna process has proved for higher education. However, the 'voices from within' convergences claim that data speaks for differentiated reproductions via common frameworks. The specific features of individual countries' education systems configure a paradoxical communality: maybe except for Malta and its small territory, they are all structurally polyphonic and impossible to fit inside one unambiguous synthesis. And when we look at educational inequalities, inner regional differences stem out as the most significative reality.

It has recently been suggested that one significant point of affinity between all these countries (and France as well) is the role of the State in its relationship with the administrative system, which influences at least the formal systems of education (Argyropoulou, 2015); while at the same time significant affinities can also be found regarding the approach to less formal educational provisions (Guimaraes et al., 2018). Nevertheless, more generally, however problematic the issue, identifying Southern Europe as one of the European regions is not supported by the sharing of similar education systems for what it may concerns both structural and institutional factors and educational outputs in terms of educational inequalities.

Even if it was not at the centerstage of our analyses, discussing the ratio of the South implies also putting under examination the sustainability — too often taken for granted — of 'Northern Europe' and of 'Continental Europe'. In other words, the epistemic as well as the political complexity of European education systems is too often overlooked. This does not mean that we cannot or should not intensify the comparative analysis between the countries of Southern Europe and between them and the rest of Europe. This kind of research is essential and valuable as it contributes to deconstruct the concept of 
the block of Southern Europe (Palomba, Cappa, 2018) and to highlight the differences and analytical similarities that each of these countries may have with other European countries.

The analysis relative to the Southern Europe countries is relatively scarce and much less refined. In the picture the hegemonic discourse appears in fact to imply a need to 'bridge the gap' towards benchmarks relative to a latent European model that is supposedly not in question: both in the case of this model being considered as shared, or else accepted with that «sense of inevitability» of which Nóvoa and Yariv-Marshal (2003) speak. Overall, through the prism of Southern European countries, we have explicitly addressed the utility of comparative education as such, asking, through the role that the education systems and inequalities substantiated within these countries may play in the wider international debate, what South-Europe education today is and to what extent it can respond to diverse perspectives that not only represent strongly topical trophism, but above all could contribute to a substantial conceptual enrichment.

\section{Bibliographical references}

Adamson, Frank; Astrand, Bjorn \& Darling-Hammond, Linda (2016). Global Education Reform: How Privatization and Public Investment Influence Education Outcomes. London: Routledge.

Argyropoulou, Eleftheria (2015): "The Role of the State in the Latin Countries: Similarities and Differences. Why and How Educational Systems' Organization Can Be Affected". Journal of Educational Cultural and Psychological Studies, 11, 319-331.

Altrichter, Herbert; Heinrich, Martin; Soukup-Altrichter, Kath (2014): "School Decentralization as a Process of Differentiation, Hierarchization and Selection". Journal of Education Policy, 29 (5), 675-699.

Ball, Stephen J. \& Youdell, Deborah (2008). Hidden Privatisation in Education. Brussels:Education International.

Benadusi, Luciano \& Giancola, Orazio (2014): "Secondary School Systems: 'Comprehensive' versus 'Selective'. A Comparison in Terms of Equity”. Scuola democratica, 2, 461-482.

Benito, Ricard; Alegre, Miquel Ángel \& Gonzàlez-Balletbò, Isaac (2014): "School Segregation and Its Effects on Educational Equality and Efficiency in 16 OECD Comprehensive School Systems”. Comparative Education Review, 58 (1), 104-34.

Busemeyer, Marius R. (2014). Skills and Inequality: Partisan Politics and the Political Economy of Education Reforms in Western Welfare States. Cambridge University Press.

Christ, Claudia \& Dobbins, Michael (2016): "Increasing School Autonomy in Western Europe: A Comparative Analysis of its Causes and Forms". European Societies, 18 (4), 359-388.

Da Cruz Martins, Susana; Albuquerque, Adriana \& Capucha, Luís (2019): "School Autonomy and Administration. Configurations and Processes in Europe" in Susana da Cruz Martins, Luís Capucha, João Sebastião, (eds): School Autonomy, Organization and Performance in Europe. A comparative analysis for the period from 2000 to 2015. Lisbon: CIES-ISCTE.

Eurydice, (2020). Compulsory Education in Europe - 2020/21. Eurydice Facts and Figures. Luxembourg: Publications Office of the European Union. 
Eurydice, (2019). The Structure of the European Education Systems 2018/19, Eurydice Facts and Figures. Luxembourg: Publications Office of the European Union.

Eurydice, (2015). Assuring Quality in Education: Policies and Approaches to School Evaluation in Europe. Luxembourg: Publications Office of the European Union.

Ferrera, Maurizio (1996): “The 'Southern Model' of Welfare in Social Europe”. Journal of European Social Policy, $6(1), 17-37$.

Forsey, Martin; Davies, Scott \& Walford, Geoffrey (2008). The Globalisation of School Choice? Oxford: Symposium Books.

Giancola, Orazio (2009). Performance e Diseguaglianze nei Sistemi Educativi Europei. Napoli: ScriptaWeb.

Giancola, Orazio \& Salmieri, Luca (2020): "Family Background, School-Track and Macro-Area: The Complex Chains of Education Inequalities in Italy". DISSE Working Papers, 4, 1-22.

Giancola, Orazio \& Salmieri, Luca (2022): “Cross-National Achievement Surveys and Educational Monitoring in Italy" in Louis Volante, Sylke V. Schnepf, Don A. Klinger (eds.): Cross-National Achievement Surveys for Monitoring Educational Outcomes. Luxembourg: Office of the European Union. (Forthcoming).

GERESE, (2005). L'équité des systèmes éducatifs européens. Un ensemble d'indicateurs. Groupe Européen de Recherche sur l'Équité des Systèmes Éducatifs, Servicede pédagogie théorique et expérimentale. Liége: Université de Liège.

Guimaraes, Paula; Lucio-Villeguas, Emilio \& Mayo, Peter (2018): "Southern-European Signposts for Critical Popular Adult Education, Italy, Portugal and Spain”. Compare, 48 (1), 56-74.

Hanushek, Eric A.; Link, Susanne \& Woessmann, Ludger (2013): "Does School Autonomy Make Sense Everywhere? Panel Estimates from PISA". Journal of Development Economics, 104, 212-232.

Hanushek, Eric A.; Woessmann, Ludger (2014): "Institutional Structures of the Education System and Student Achievement: A Review of Cross-Country Economic Research" in Rolf Strietholt, Wilfried Bos, Jan-Eric Gustafsson and Monica Rosén, (eds.): Educational Policy Evaluation Through International Comparative Assessments. Münster-New York: Waxmann.

Jeong, Dong Wook \& Luschei, Thomas F. (2018): “Are Teachers Losing Control of the Classroom? Global Changes in School Governance and Teacher Responsibilities, 2000-2015”. International Journal of Educational Development, 62, 289-301.

Korpi, Walter (2000): "Faces of Inequality: Gender, Class, and Patterns of Inequalities in Different Types of Welfare States”. Social Politics: International Studies in Gender, State \& Society, 7 (2), 127-191.

Madeira, Ana Isabel (2018): "The Structuration of Comparative Discourse and the Imagination of Knowledge Spaces: Portugal, the 'South of Europe', and the 'South below"'. Comparative Education, 54 (4), 459-489.

Maslowski, Ralf; Scheerens, Jaap \& Luyten, Hans (2007): “The Effect of School Autonomy and School Internal Decentralization on Students' Reading Literacy". School Effectiveness and School Improvement, $18(3), 303-334$. 
Mifsud, Denise (2021): "Social Justice and Education in the Maltese State School System Some Political and Practical Issues" in Denise Mifsud \& Paolo Landri (eds.): Enacting and Conceptualizing Educational Leadership within the Mediterranean Region. Leiden, Netherlands: Brill.

Mifsud, Denise \& Landri, Paolo (2021): "Problematizing the Dominant Discourses and Policies of Educational Leadership within the Mediterranean Basin" in Denise Mifsud \& Paolo Landri (eds.): Enacting and Conceptualizing Educational Leadership within the Mediterranean Region. Leiden, Netherlands: Brill.

Nóvoa, António (2018): "Comparing Southern Europe: the Difference, the Public, and the Common". Comparative Education, 54 (4), 548-561.

Nóvoa, António \& Yariv-Marshal, Tali (2003): "Comparative Research in Education: A Mode of Governance or a Historical Journey?”. Comparative Education, 39 (4), 423-438.

OECD, (2012). Equity and Quality in Education: Supporting Disadvantaged Students and Schools. OECD Publishing.

Palomba, Donatella \& Cappa, Carlo (2018): "Comparative Studies in Education in Southern Europe", Comparative Education, 54 (4), 435-439.

Pensiero, Nicola; Giancola, Orazio \& Barone, Carlo (2019). "Socioeconomic Inequality and Student Outcomes in Italy" in Louis Volante, Sylke V. Schnepf, Don A. Klinger (eds.): Socioeconomic Inequality and Student Outcomes. Singapore: Springer.

Rhodes, Martin (1996): "Southern European Welfare States: Identity, Problems and Prospects for Reform". South European Society and Politics, 1 (3), 1-22.

Rowe, Emma E. \& Lubienski, Christopher (2017): “Shopping for Schools or Shopping for Peers: Public Schools and Catchment Area Segregation". Journal of Education Policy, 32 (3), 340-356.

Salmieri, Luca \& Giancola, Orazio (2021): "La pobreza educativa en España en una comparación europea”. Revista Española de Sociología, 30 (2), a48.

Urquiola, Miguel (2016): "Competition Among Schools: Traditional Public and Private Schools" in Eric A. Hanushek, Stephen J., Machin \& LudgerWoessmann, (eds): Handbook of the Economics of Education, Vol. 5. Amsterdam: North-Holland.

Wermke, Wieland \& Salokangas, Maija (2015): "Autonomy in Education: Theoretical and Empirical Approaches to a Contested Concept". Nordic Journal of Studies in Educational Policy, 2, 1-6.

\section{Biographical notes}

Orazio Giancola is Associate Professor at the Department of Social and Economic Sciences of the Sapienza University of Rome. His main areas of interest are: sociology of educational systems, analysis of educational and university policies, educational and social inequalities, methods and techniques for social and evaluative research. Among his latest publications: Socioeconomic Inequality and Student Outcomes in Italian Schools (with Barone C. \& Pensiero N. in Volante L. et al., 2019); Icts overuse in the European educational space. Interpreting the Icts overdose on learning outcomes, in Sociologia e Ricerca Sociale (with Salmieri L., 2020). 
Giancola, O., Cross-National Achievement Surveys and Educational Monitoring in Italy, in Volante L., Schnepf S. V., Klinger D. (with Salmieri L., 2022).

Luca Salmieri, PhD in Gender and Family History, is Associate Professor of Sociology and Culture at Sapienza-University of Rome. He is co-editor in chief of the journal Scuola Democratica and member of the editorial board of the International Review of Sociology. He has carried out research on education, learning\&training activities, and youth transition to adult life. Among his latest publications: The Education of Gender. The Gender of Education. Sociological Research in Italy with Maddalena Colombo and La pobreza educativa en España en una comparación europea, with Orazio Giancola. 